\title{
Cloud Computing of E-Government
}

\author{
Tamara Almarabeh, Yousef Kh. Majdalawi, Hiba Mohammad \\ Computer Information System Department, The University of Jordan, Amman, Jordan \\ Email: t.almaraabeh@ju.edu.jo,ymajdal@ju.edu.jo,h.khadrawi@ju.edu.jo
}

Received 5 January 2016; accepted 15 February 2016; published 18 February 2016

Copyright (C) 2016 by authors and Scientific Research Publishing Inc.

This work is licensed under the Creative Commons Attribution International License (CC BY).

http://creativecommons.org/licenses/by/4.0/

(c) (7) Open Access

\begin{abstract}
Over the past years, many businesses, government and individuals have been started to adopt the internet and web-based technologies in their works to take benefits of costs reduction and better utilization of existing resources. The cloud computing is a new way of computing which aims to provide better communication style and storage resources in a safe environment via the internet platform. The E-governments around the world are facing the continued budget challenges and increasing in the size of their computational data so that they need to find ways to deliver their services to citizens as economically as possible without compromising the achievement of desired outcomes. Considering E-government is one of the sectors that is trying to provide services via the internet so the cloud computing can be a suitable model for implementing E-government architecture to improve E-government efficiency and user satisfaction. In this paper, the adoption of cloud computing strategy in implementing E-government services has been studied by focusing on the relationship between E-government and cloud computing by listing the benefits of creation E-government based on cloud computing. Finally in this paper, the challenges faced the implementation of cloud computing for E-government are discussed in details. As a result from understanding the importance of cloud computing as new, green and cheap technology is contributed to fixing and minimizing the existing problems and challenges in E-government so that the developed and developing countries need to achieve E-government based on cloud computing.
\end{abstract}

\section{Keywords}

E-Government, Cloud Computing, NIST, Software as a Service, G2G

\section{Introduction}

The world has noticed a technological revolution in the early 1990s, which is almost similar to the industrial revolution of the 20th century. This revolution, has given new communication methods and ways to different organizations and societies around the world. The researchers make a use of the existing integrated computer based systems, and communication technologies, to make the discovery that through the use of telecommunica- 
tion networks and computer based systems, information in all forms and kinds can spread to all over the world.

So, as a result to integrate with, and supplement fax and telephones, a new communication medium is introduced to the world, which is known as internet. Later, the internet becomes the World Wide Web (www) and the integration with the computer and communication technologies as well. A new more developed and enhanced technology comes out as a result, which is known as e-technologies or web-enabled technologies.

After that, all organizations start to own its own place on the web, by building their own web-sites which have all the information required about them in a more developed and advanced stage, depending on the development of all the network systems, and communication systems (infrastructure). Organizations have started to do transactions online, and this idea comes up with the E-business, or E-commerce, and E-government.

Over the past decade, governments across the world and at all levels have adopted electronic government. However, many developing countries still face difficulties to implement E-government initiatives, leading to a high level of failure [1] [2]. The most experienced challenges and barriers across the relevant studies include technological barriers, lack of resources, cost, digital divide, poor management and infrastructure, and lack of IT infrastructure [1] [3]-[5].

The continuous advancements in technologies related to implementing and delivering E-government services may provide opportunities to overcome some of these challenges enhance and make the implemented systems more effective. E-governments around the world are seriously looking into cloud computing as mean of increasing efficiency, reducing cost, providing more reliable and efficient services, and reducing cycle time [6].

Cloud computing is one of the new technologies which can significantly improve a government function, the services it provides to its citizens and institutions, and its cooperation with other governments. Traditional processes for planning, developing, and testing IT capabilities contrast with the new need to act quickly when experimenting with new ideas. Cloud computing is an approach that can provide capabilities quickly.

This paper is organizes as follows: In Section 2, E-government concept and its types have been discussed. In Section 3, cloud computing basics have been explained. Section 4 describes cloud computing benefits and challenges of E-government, and Section 5 concludes the research with the future work.

\section{Definition and Importance of E-Government}

It is believed that the first use of the term E-government was Clinton-AL Gore administration's in 1993 [7]. World Bank website provided definition of E-government as [8]: E-government" refers to the use by government agencies of information technologies (such as Wide Area Networks, the Internet, and mobile computing) that have the ability to transform relations with citizens, businesses, and other arms of government. These technologies can serve a variety of different ends: better delivery of government services to citizens, improved interactions with business and industry, citizen empowerment through access to information, or more efficient government management. The resulting benefits can be less corruption, increased transparency, greater convenience, revenue growth, and/or cost reductions".

An interesting distinction between E-government and E-governance was introduced by Bhatnagar in 2003 where he defined the "E-government is concerned with improving access to government functions, be they services or information. The term thus differs from E-governance where it is a broader concept covering the use of the Internet by politicians or political parties to elicit views from their constituencies or the publishing of views by civil society organizations" [9].

Accordingly and for the purpose of this study E-government can be defined as:

1) E-government is new ways being used to reinvent the business of government, includes making the information accessible on the web, and delivering all the services on the web too in an easy fast and reliable way regardless to the distances and time.

2) It is also transforming the nature of governance by affecting the relationship and responsibility between the state and its citizens [10].

The researchers adopted the above mentioned definition because of its simplicity and flexibility. It also gives the E-government a wide definition that describes the E-government processes rather than describing its results. E-government is a huge information system project to be built by government, and offers electronic services to four types of customers (Table 1): businesses, citizens, employees, and government itself [11]-[15].

E-government tries to provide multiple of government process in the best way to perform a daily activities 
Table 1. E-government categories.

\begin{tabular}{|c|c|c|}
\hline Abbreviation & Category & Definition \\
\hline G2B & Government to business & $\begin{array}{l}\text { This category includes interactions between governments and businesses } \\
\text { [16]-[18]. Example: access to current information, renewing and obtaining } \\
\text { licenses, registration of companies, and payment of taxes [16] [19]. }\end{array}$ \\
\hline G2C & Government to citizen & $\begin{array}{l}\text { This category includes all the interactions between a government and its } \\
\text { citizens [20] [21]. Example: Renewing a driver's license and paying traffic } \\
\text { fine [18] [22]-[24]. }\end{array}$ \\
\hline G2E & Government to employee & $\begin{array}{l}\text { This category refers to the relationship between thE-government and its } \\
\text { employees [16] [25] [26]. } \\
\text { Example: giving employees access to training, e-mail, e-learning, and } \\
\text { authorizations to access databases to gain information needed to complete } \\
\text { services [25] [27] [28]. }\end{array}$ \\
\hline G2G & Government to government & $\begin{array}{l}\text { This category includes delivering the services, sharing databases and } \\
\text { resources between government departments and agencies [20] [21]. }\end{array}$ \\
\hline
\end{tabular}

such as digitalization of citizen record, receive community feedback, and automation of tax collection using modern and latest technologies to improve the way of providing effective services, to increase their ability to collaborate and interact with citizens, and to achieve greater transparency [29].

E-government is facing different type of challenges such as technical, organizational and economical challenges which puts governments under pressure to be innovative. Innovative means that E-government should benefits from the latest ICTs (Information and Communication Technologies), which increase the efficiency and the effectiveness of the public sector.

\section{Definition and Importance of Cloud Computing}

Cloud computing is a revolutionary concept for many businesses, governments and citizens. According to Gather, by 2012, 20\% of businesses will adopt cloud services and own no IT assets [30]. Cloud computing have various definitions which some have been brought here. One of the reasons why cloud computing has multiple definitions is that cloud computing does not refer to a specific technology but rather to a concept comprising a set of combined technologies [31].

IEEE Computer Society defined Cloud computing as: “A paradigm in which information is constantly stored in servers on the Internet and cached temporarily on clients that include desktops, entertainment centers, computers, notebooks, handhelds, etc.” [32]. It is the delivery of computing as a service rather than a product, where by shared resources, software and information are produced to computers and other devices as a metered over a network.

Many scientists of the National Institute of Standards and Technology (NIST) that work on cloud computing in America defined it as follows [33]: "Cloud computing is a model for enabling convenient to access to networks and applications quickly, common set of configurable computing resources (e.g., networks, servers, storage and applications) that can work with little or interfere with the service provider to provide or be released immediately."

Another definition of Berkeley RAD Lab [34] is cloud computing refers to both the applications delivered as services over the Internet and the hardware and systems software in the datacenters that provide those services. The services themselves have long been referred to as Software as a Service (SaaS), so we use that term. The datacenter hardware and software is what we will call the cloud.

The definition of NIST focuses more on the purpose of cloud computing, where the second concentrates more on the components of cloud computing. They show that cloud computing can be understood as a service model for computing services based on a set of computing resources that can be accessed in a flexible, elastic, on-demand way with low management effort. The following characteristics, which are generally inherent to cloud computing as shown in Figure 1 [33]:

1) Broad network access: Resources are virtually accessible via the Internet regardless the location and the device used (i.e., mobile phones, tablets, laptops, and workstations).

2) On-demand self-service: Computing capabilities, such as server and processing time, and network storage, are provided automatically as needed. 


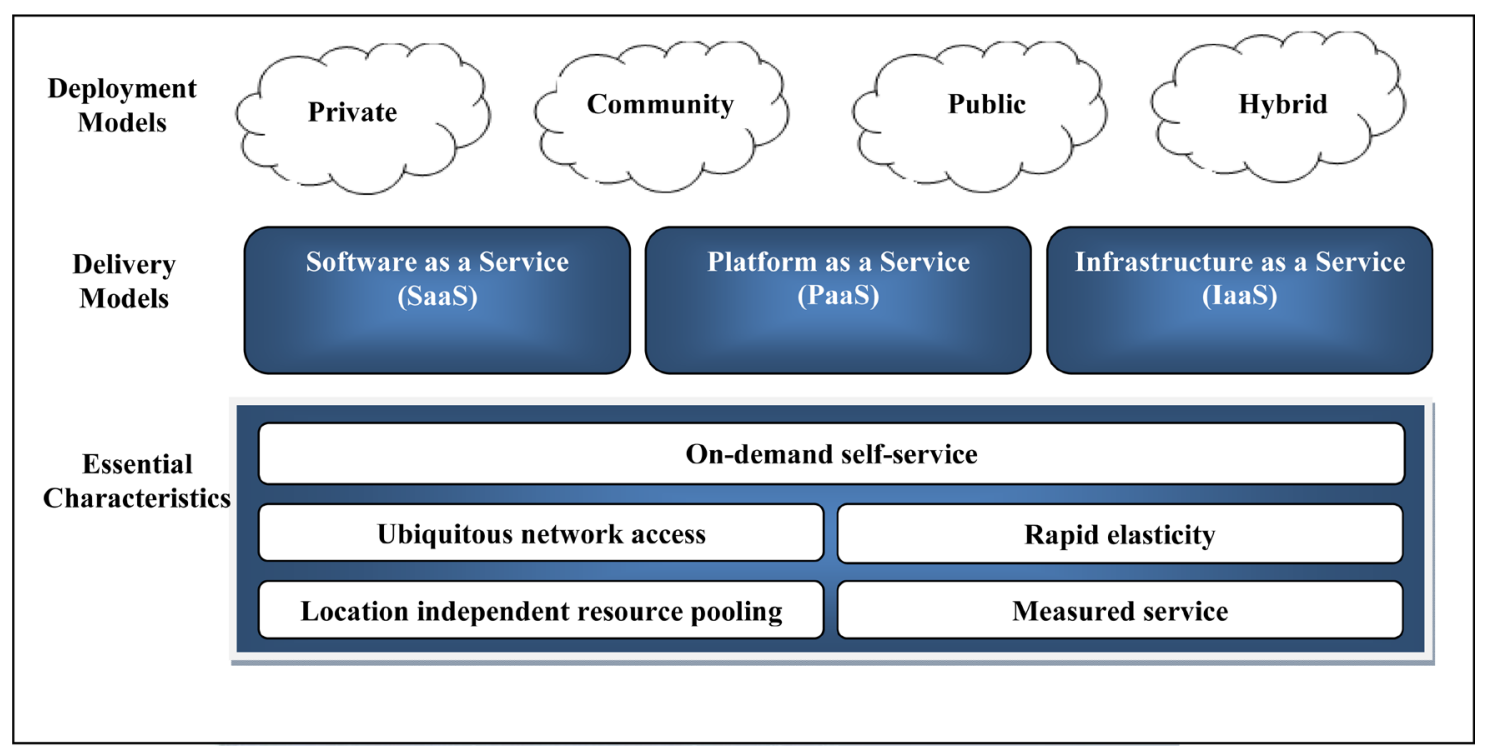

Figure 1. NIST cloud computing definition. Based on: NIST working definition of cloud computing v14 and NIST presentation on effectively and securely using the cloud computing paradigm v22 http://www.csrs.nist.gov/groups/SNS/cloud-computing/index.html.

3) Resource pooling: The resources are pooled to serve different clients with physical and virtual resources dynamically appointed and reassigned as per client request.

4) Measured service: Controlling and optimizing resource use by assigning a measured capability appropriate to the type of service (i.e., storage, processing and bandwidth).

5) Rapid elasticity: Resources can be provisioned and to be scaled rapidly outward and inward commensurate with demand.

Cloud computing provides three fundamental service models which also shown in Figure 1.

1) Software as a Service (SaaS): Software application is offered as a service where the client doesn't control or manage any cloud infrastructure, i.e. applications like customer relationship management (CRM), Email, Instant messaging (IM), office productivity applications that are offered as a service by a cloud vendor.

2) Platform as a Service (PaaS): Provides required platform to develop and customize applications.

3) Infrastructure as a Service (IaaS): Provides hardware infrastructure (servers, O.S, storage, network on demand).

With cloud computing technology, large pools of resources can be connected through private or public networks. This technology simplifies infrastructure planning and provides dynamically scalable infrastructure for cloud based applications, data, and file storage. Businesses can choose to deploy applications on one of the following models:

1) Public Cloud: all customers can share the same infrastructure pool with limited configuration, security protections and availability variances. The customers take benefit from economies of scale, because infrastructure costs are spread across all users.

2) Private Cloud (also known as internal cloud): cloud infrastructure dedicated to a particular organization which it is not shared with other organizations. It will require the organization to reevaluate decisions about existing resources. Private clouds are more expensive but also more secure when compared to public clouds.

3) Hybrid Cloud: These Clouds are a composition of two or more clouds to take the advantages of multiple deployment models such as increasing the flexibility of computing.

4) Community Cloud: means sharing computing infrastructure by organizations of the same community.

The different types of cloud computing models offers many potential benefits to organizations such as reduced infrastructure costs, unlimited data storage, recovery and backup and ease access to information.

\section{Relationship between E-Government and Cloud Computing}

Cloud computing is used to help the E-governments in providing best possible services to its stockholders i.e. 
citizens and businesses, and to reduce the costs by reducing repetitive operations and increase the effective use of resources, in the global arena.

Some agencies in Australia seek for innovative ways to deliver government services and want to rationalize their ICT asset so they commenced small pilots to evaluate the potential of application, platforms and infrastructure cloud computing. The agencies are listed in Table 2 [35].

In 2011 the UK government published its ICT strategy which covered the cloud computing and involved reducing ICT costs for governments, optimizing the use of data center infrastructure, and increasing public sector agility [36] using G-Cloud(Government Cloud).

While Kuwait cloud computing was established in 2006 and has achieved several projects involving data infrastructure which are needed to develop E-government that incorporates relevant official bodies. It established a data network that links over 56 governmental bodies, sharing electronic documents and data at a very high speed where the aim of using cloud computing is for easy data recalling and storage.

Cloud computing technologies have many benefits in different parts of E-government. These benefits discussed in the following points.

1) Scalability: Cloud computing resources such as CPU, servers, hard drives can be purchased automatically in any quantity at any time to fit growing number of users [37]-[44].

2) Availability and Accessibility: cloud computing applications and information are hosted online therefore it has high availability and citizens can use them at anytime and from anywhere [37] [39]-[45].

3) Cost Saving: cloud computing systems do not need to purchase and install the ICT equipments and software on their own building [37] [39]-[42] [44]-[49].

4) Backup and Recovery: Since all the data is stored in the cloud, backing it up and restoring is much simpler than traditional way [50].

5) Unlimited Storage. Storing information in the cloud gives you almost unlimited storage capacity.

6) Green technology: Cloud computing is relatively good in energy consumption and provides eco-systems through virtual services [39] [42] [46] [49].

Due to cloud computing benefits as mentioned above, many countries have launched E-governance services using cloud computing [50].

Although cloud computing offers a lot of advantages to E-government, several issues and challenges need to be targeted or to be met when applying cloud computing.

The main issues and challenges for adopting cloud computing for the E-government are:

1) Security and privacy: Security requirements must be fulfilled on several layers where the Implementation of cloud computing includes advanced security technologies [37] [40] [51]-[53].

2) Data protection and compliance: some data protection regulations do not allow the storage of sensitive data in other countries, which is basically not accomplished by most cloud service providers.

Table 2. Agencies of Austria with their pilots projects of cloud computing.

\begin{tabular}{|c|c|}
\hline Agency & Pilots/implementation of cloud computing \\
\hline West Australian Department of Treasury and Finance (DTF) & DTF implemented private cloud. This was announced in August 2010. \\
\hline West Australian Health (WA Health) & $\begin{array}{l}\text { WA Health implemented private cloud. This was announced } \\
\text { in August } 2010 \text { and anticipated competition for WA } \\
\text { Health data centers were in April } 2011 \text { and June } 2011 .\end{array}$ \\
\hline Department of Immigration and Citizenship (DIAC) & $\begin{array}{l}\text { DIAC implemented hybrid cloud and important } \\
\text { issue was centrality versus distributed centers. }\end{array}$ \\
\hline Department of Human Services (DHS) & $\begin{array}{l}\text { DHC implemented public cloud and this department is } \\
\text { only in the stage of the proof of concept. }\end{array}$ \\
\hline Australian Maritime Safety Authority (AMSA) & $\begin{array}{l}\text { AMSA implemented public cloud. This department } \\
\text { adopted cloud computing of pilot-cloud based application } \\
\text { on a vendor platform (Force.com). }\end{array}$ \\
\hline $\begin{array}{l}\text { Australian Government Information } \\
\text { Management Office (AMIGO) }\end{array}$ & $\begin{array}{l}\text { AMIGO adopted IaaS and PaaS cloud computing delivered models. } \\
\text { The data sets on the data.gov.au were migrated onto the public } \\
\text { Amazon cloud. The data.gov.au and govspace.gov.au } \\
\text { websites were migrated onto a private cloud. }\end{array}$ \\
\hline
\end{tabular}


3) Interoperability and data portability: There is a lack of standards when using and implementing cloud computing services. Users should be able to change between cloud service providers with a minimum of risk and cost, so governments may need to adopt open standards policies for the cloud [54]. Many governments decided to use ICT systems that consistent to open standards in order to save the cost or that can take place when using nonstandard systems. [40] [52].

4) Identity and access management: As cloud computing services relies completely on the availability and speed of the Internet as a carrier between consumer and service provider, speed and availability will be an issue [53].

5) Auditing: Cloud providers currently do not offer detailed auditing possibilities where the auditing becomes essential in situations where compliance to specific regulations or policies must be verified.

Several technical challenges like Data scaling, auditing and logging, rolling out new Instances, replication and migration, disaster recovery, policy management, system integration and legacy software, obsolete technologies and migration to new technologies [8]. Some Arab governments have developed modern suite of laws which strongly facilitate and support cloud computing. For example, Saudi Arabia put comprehensive privacy legislation besides intellectual property laws that are relevant to cloud computing.

\section{Conclusions and Future Work}

Cloud computing is actually working to help break down the barriers of many governments to enter new phase of collaboration and partnering, sharing services, and pooling of resources. It offers an effective way to share information between citizens, reducing efforts in providing services, budget management and cost effective.

This paper gives insight to the issues of cloud computing in E-government and investigates the importance of the new technologies to be adopted in implementing E-government such as cloud computing which provides the overall strategy and techniques to manage E-government content in general.

In the future, we will study how to implement E-government services using cloud computing in more details by giving some suggestions in how to select the most effective services in the cloud to achieve a best implementation of E-government using cloud computing and we will give special emphasis to Jordan.

\section{References}

[1] Al Al-Rashidi, H. (2013) The Role of Internal Stakeholders and Influencing Factors during the Phases of E-Government Initiative Implementation. Brunel University, School of Information Systems, Computing and Mathematics, Uxbridge.

[2] Shareef, M.S., Pimenidis, E., Arreymbi, J. and Jahankhani, H. (2010) Vision of Electronic Government implementation in Kurdistan region of Iraq. 10th European Conference on E-Government ECEG 2010, Limerick, 17-18 June 2010, Academic Conferences Limited, Reading, 575-584.

[3] Al-Sobhi, F. and Weerakkody, V. (2009) The Role of Intermediaries in Facilitating E-Government Diffusion in Saudi Arabia. European and Mediterranean Conference on Information Systems 2010, Abu Dhabi, 12-13 April 2009, 1-17.

[4] Rana, N.P., Dwivedi, Y.K. and Williams, M.D. (2013) Analysing Challenges, Barriers and CSF of Egov adoption. Transforming Government: People, Process and Policy, 7, 177-198. http://dx.doi.org/10.1108/17506161311325350

[5] Shin, S., Song, H. and Kang, M. (2008) Implementing E-Government in Developing Countries: Its Unique and Common Success Factors. American Political Science Association, 28-31 August 2008. http://195.130.87.21:8080/dspace/bitstream/123456789/1025/1/Implementing\%20e-government\%20in\%20developing \%20countries\%20its\%20unique\%20and\%20common\%20success\%20factors.pdf

[6] VijayKumar, N. (2011) Role of ICT in E-Governance: Impact of Cloud Computing in Driving New Initiatives. SETLabs Briefings, 9, 43-55.

[7] Luna-Reyes, L.F., Pardo, T.A., Gil-Garcia, J.R., Navarrete, C., Zhang, J. and Mellouli, S. (2010) Digital Government in North America: A Comparative Analysis of Policy and Program Priorities in Canada, Mexico, and the United States. Comparative E-Government, 139-160. http://dx.doi.org/10.1007/978-1-4419-6536-3_7

[8] The World Bank Group (2009) Definition of E-Government, World Wide Web. http://www.worldbank.org/egov

[9] Sheridan, W. and Riley, T.B. (2006) Comparing E-Government vs. E-Governance. eGov Monitor. Knowledge Asset Management Limited, London.

[10] Atallah, S. (2015) E-Government: Consideration for Arab States. UNDP April 2001. http://www.mafhoum.com/press/56T41.pdf 
[11] Badri, M.A. and Alshare, K. (2008) A Path Analytic Model and Measurement of the Business Value of E-Government: An International Perspective. International Journal of Information Management, 28, 524-535. http://dx.doi.org/10.1016/j.ijinfomgt.2006.10.004

[12] Arpac1, I. and Arifoğlu, A. (2009) E-Transformation and Technological Innovation in Turkey. Proceedings of the European and Mediterranean Conference on Information Systems (EMCIS). İzmir, 13-14 July 2009, 1-9.

[13] Valdés, G., Solar, M., Astudillo, H., Iribarren, M., Concha, G. and Visconti, M. (2011) Conception, Development and Implementation of an E-Government Maturity Model in Public Agencies. Government Information Quarterly, 28, 176187. http://dx.doi.org/10.1016/j.giq.2010.04.007

[14] Jayashree, S. and Marthandan, G. (2010) Government to E-Government to E-Society. Journal of Applied Sciences, 10, 2205-2210. http://dx.doi.org/10.3923/jas.2010.2205.2210

[15] Huang, K. (2010) The Relations and Interactions of E-Government and E-Commerce. Proceedings of the International Conference on Educational and Network Technology (ICENT), Qinhuangdao, 25-27 June 2010, 527-530. http://dx.doi.org/10.1109/icent.2010.5532221

[16] Al Nagi, E. and Hamdan, M. (2009) Computerization and E-Government Implementation in Jordan: Challenges, Obstacles and Successes. Government Information Quarterly, 26, 577-583. http://dx.doi.org/10.1016/j.giq.2009.04.003

[17] Rowley, J. (2011) E-Government Stakeholders-Who Are They and What Do They Want? International Journal of Information Management, 31, 53-62. http://dx.doi.org/10.1016/j.ijinfomgt.2010.05.005

[18] Sagheb-Tehrani, M. (2010) A Model of Successful Factors towards E-Government Implementation. Electronic Government: An International Journal, 7, 60-74. http://dx.doi.org/10.1504/EG.2010.029891

[19] Fang, Z. (2002) E-Government in Digital Era: Concept, Practice, and Development. International Journal of the Computer, the Internet and Management, 10, 1-22.

[20] Lee, S.M., Tan, X. and Trimi, S. (2005) Current Practices of Leading E-Government Countries. Communications of the ACM, 48, 99-104. http://dx.doi.org/10.1145/1089107.1089112

[21] Torres, L., Pina, V. and Acerete, B. (2005) E-Government Developments on Delivering Public Services among EU Cities. Government Information Quarterly, 22, 217-238. http://dx.doi.org/10.1016/j.giq.2005.02.004

[22] Carter, L. and Belanger, F. (2004) The Influence of Perceived Characteristics of Innovating on E-Government Adoption. Electronic Journal of E-Government, 2, 11-20.

[23] Reddick, C.G. (2005) Citizen Interaction with E-Government: From the Streets to Servers? Government Information Quarterly, 22, 38-57. http://dx.doi.org/10.1016/j.giq.2004.10.003

[24] Reinwald, A. and Kraemmergaard, P. (2012) Managing Stakeholders in Transformational Government-A Case Study in a Danish Local Government. Government Information Quarterly, 29, 133-141. http://dx.doi.org/10.1016/j.giq.2011.09.007

[25] Ndou, V. (2004) E-Government for Developing Countries: Opportunities and Challenges. EJISDC, 18, 1-24.

[26] Chourabi, H. and Mellouli, S. (2011) E-Government: Integrated Services Framework. Proceedings of the 12th Annual International Digital Government Research Conference: Digital Government Innovation in Challenging Times, College Park, 12-15 June 2011, 36-44. http://dx.doi.org/10.1145/2037556.2037563

[27] Carbo, T. and Williams, J.G. (2004) Some Determinants of User Perceptions of Information Quality on the World Wide Web. Electronic Journal of E-Government, 2, 94-105.

[28] Sharma, S.K. and Gupta, J.N.D. (2004) Web Services Architecture for M-Government: Issues and Challenges. Electronic Government: An International Journal, 1, 462-474. http://dx.doi.org/10.1504/EG.2004.005921

[29] Veljanovska, K. and Zdravevska, V. (2013) E-Government Based on Cloud Computing. Journal of Emerging Trends in Computing and Information Sciences, 4, 377-381.

[30] Malone, A. (2011) Workshop. The Cloud Chronicles: Security over the Rainbow. 6 October 2011, 4-9.

[31] Schubert, L., Jefferey, K. and Neidecker-Lutz, B. (2010) The Future of Cloud Computing: Opportunities for European Cloud Computing beyond 2010, Public Version 1.0. http://cordis.europa.eu/fp7/ict/ssai/docs/cloud-report-final.pdf

[32] Kho, N.D. (2009) Content in the Cloud. E Content, 32, 26-30.

[33] The National Institute of Standards and Technology. http://csrc.nist.gov/publications/nistpubs/800-145/SP800-145.pdf

[34] Armbrust, M., Fox, A., Griffith, R., Joseph, A., Katz, R., Konwinski, A., Lee, G., Patterson, D., Rabkin, A., Stoica, I. and Zaharia, M. (2009) Above the Clouds: A Berkeley View of Cloud Computing. UC Berkeley Reliable Adaptive Distributed (RAD) Systems Laboratory, Berkeley. www.eecs.berkeley.edu/Pubs/TechRpts/2009/EECS-2009-28.pdf

[35] Australian Government, Department of Finance and Deregulation, Cloud Computing Strategic Direction Paper, Opportunities and Applicability for Use by the Australian Government, Version 1.0, Page 5-10, 22, 31, April 2011. 
[36] UK Cabinet Office (2011) Government ICT Strategy. http://www.cabinetoffice.gov.uk/content/government-ict-strategy

[37] Alshomrani, S. and Qamar, S. (2013) Cloud Based E-Government: Benefits and Challenges. International Journal of Multidisciplinary Sciences and Engineering, 4, 1-7.

[38] Tripathi, A. and Parihar, B. (2011) E-Governance Challenges and Cloud Benefits. Proceedings of the IEEE International Conference on Computer Science and Automation Engineering (CSAE), Shanghai, 10-12 June 2011, 351-354. http://dx.doi.org/10.1109/CSAE.2011.5953237

[39] Das, R.K., Patnaik, S. and Misro, A.K. (2011) Adoption of Cloud Computing in E-Governance. In: Meghanathan, N., Kaushik, B.K. and Nagamalai, D., Eds., Advanced Computing, Springer, Berlin, 161-172. http://dx.doi.org/10.1007/978-3-642-17881-8_16

[40] Liang, J. (2012) Government Cloud: Enhancing Efficiency of E-Government and Providing Better Public Services. Proceedings of the 2012 International Joint Conference on Service Sciences (IJCSS), Shanghai, 24-26 May 2012, 261265. http://dx.doi.org/10.1109/IJCSS.2012.20

[41] Astogi, A. (2010) A Model Based Approach to Implement Cloud Computing in E-Governance. International Journal of Computer Applications, 9, 15-18.

[42] Sharma, R., Sharma, A. and Singh, R.R. (2012) E-Governance \& Cloud Computing: Technology Oriented Government Policies. IJRIM, 2, 584-593.

[43] Bhisikar, A. (2011) G-Cloud: New Paradigm Shift for Online Public Services. International Journal of Computer Applications, 22, 24-29. http://dx.doi.org/10.5120/2603-3629

[44] Zwattendorfer, B. and Tauber, A. (2013) The Public Cloud for E-Government. International Journal of Distributed Systems and Technologies (IJDST), 4, 1-14. http://dx.doi.org/10.4018/ijdst.2013100101

[45] Bellamy, M. (2013) Adoption of Cloud Computing Services by Public Sector Organizations. Proceedings of the IEEE Ninth World Congress on Services (SERVICES), Santa Clara, CA, 28 June-3 July 2013, 201-208. http://dx.doi.org/10.1109/services.2013.50

[46] Bansal, K.L., Sharma, S.K. and Sood, S. (2012) Impact of Cloud Computing in Implementing Cost Effective E-Governance Operations. Gian Jyoti E-Journal, 1, 1-12.

[47] Craig, R., Frazier, J., Jacknis, N., Murphy, S., Purcell, C., Spencer, P., et al. (2009) Cloud Computing in the Public Sector: Public Manager's Guide to Evaluating and Adopting Cloud Computing. White Paper, Cisco Internet Business Solutions Group.

[48] Kundra, V. (2010) State of Public Sector Cloud Computing. Federal Chief Information Officers Council. https://cio.gov/wp-content/uploads/downloads/2012/09/StateOfCloudComputingReport-FINAL.pdf

[49] Sharma, R., Sharma, A. and Pandey, U.S. (2011) E-Governance: A Successful Implementation of Government Policies Using Cloud Computing. IJCA Proceedings on International Conference on Web Services Computing, 1, 27-29.

[50] Sharma, M. and Thapliyal, M. (2011) G-Cloud-(E-Governance in Cloud). International Journal of Engineering Science and Technology, 2, 134-137.

[51] Mukherjee, K. and Sahoo, G. (2012) A Novel Methodology for Security and Privacy of Cloud Computing and Its Use in E-Governance. Proceedings of the IEEE World Congress on Information and Communication Technologies (WICT), Trivandrum, 30 October-2 November 2012, 561-566. http://dx.doi.org/10.1109/wict.2012.6409140

[52] Yeh, C., Zhou, Y., Yu, H. and Wang, H. (2010) Analysis of E-Government Service Platform Based on Cloud Computing. Proceedings of the 2nd International Conference on Information Science and Engineering (ICISE), Hangzhou, 4-6 December 2010, 997-1000.

[53] Sahu, B.L. and Tiwari, R. (2012) A Comprehensive Study on Cloud Computing. International Journal of Advanced Research in Computer Science and Software Engineering, 2, 33-37.

[54] ATSE (2010) Cloud Computing: Opportunities and Challenges for Australia. Report of a Study by the Australian Academy of Technological Sciences and Engineering (ATSE), Melbourne. 